\section{What is the minimum a doctor should know about health economics?}

\section{Qual o mínimo que um médico deve entender de economia da saúde?}

Philip Musgrove 1

1 World Health Organization Room 4123, 20 Av. Appia, 1211 Geneva, Switzerland musgrovep@who.int

\begin{abstract}
A doctor need not learn a great deal of economics in order to understand some of the basic ideas of health economics. What is more important than any particular piece of knowledge is to understand how economists think, particularly how and why they think about markets. Health economics emphasizes some market failures which lead to poor health outcomes or high costs or both, and it concentrates especially on issues of how health care is paid for - the sources of funding, the pooling of those funds to provide protection from financial risk, and their use to purchase goods and services. Better understanding between economists and health professionals can reduce incomprehension and antagonism, and offer opportunities for more efficient and equitable health systems.
\end{abstract}

Key words Health economics, Physicians, Knowledge, attitudes, practice
Resumo Um médico não precisa saber muito de economia para entender algumas idéias básicas da economia da saúde. Mais importante do que qualquer conhecimento específico, é entender como os economistas pensam, sobretudo como e por quê eles pensam sobre os mercados. A economia da saúde enfatiza certos fracassos de mercado que geram maus resultados em saúde, ou custos altos, ou ambas as coisas. Concentra-se, especialmente, no financiamento da saúde - as fontes de recursos, sua aglomeração para proteger as pessoas contra riscos financeiros, $e$ seu uso para comprar bens e serviços. Um melhor entendimento entre economistas e profissionais médicos pode reduzir incompreensões e antagonismos, como também oferecer oportunidades para sistemas de saúde mais eficientes e mais eqüitativos.

Palavras-chave Economia da saúde, Médicos, Conhecimentos, atitudes, prática 


\section{Why do doctors need to know any health economics?}

The answer to this question is not obvious: after all, when a physician is actually practicing medicine there seems to be no room or need for economic understanding. In fact, it might get in the way, when what the doctor wants is to concentrate on the patient before him or her and bring to bear all his or her medical knowledge, which is typically much more detailed - and certainly more important at the moment of diagnosis or treatment - than what an economist typically knows or thinks about. And doctors have been treating patients, well or badly, for centuries without troubling themselves with economic concerns.

Economics perhaps has no place in the surgery, the consulting room or the laboratory, but that is not what matters. In each of those settings, resources are being used and a production process is under way, supposedly for the benefit of a consumer - and the use of limited resources to produce goods and services for intermediate or ultimate consumers is what economics is primarily about. How those resources are themselves produced, how they are combined, who chooses what to produce with them, who will pay for them, and what all that costs, create the setting in which the physician operates. Almost everything that happens prior to the encounter between the physician and the patient is relevant to the economist, even if the latter is kept outside of the medical practice itself. If there is something the doctor ought to know of health economics, it concerns those prior steps, including many of the factors that bring the patient to his or her attention in the first place.

There are at least three reasons why a physician might disregard this argument and suppose that economics has nothing useful to offer his or her profession. One is the fact that health economics is a relatively new subdiscipline. The seminal article explaining some of the subtleties that distinguish health from other sectors, particularly in relation to how it is financed, was published only in 1963.1 That opened the whole field of inquiry into risks and information that characterize health economics today and that has become steadily more important as more and more of health care is financed by insurance and the costs of it have risen. The Journal of Health Economics, the first publication devoted entirely to the subject, began to publish only in 1982; by now there is an entire two-volume Handbook of Health Economics ${ }^{2}$ and a number of journals that publish on the subject. Economists are quick to "invade" fields they find interesting, and the practicioners of those subjects may take time to notice that they have become of economic interest.

A second reason is the mistaken supposition that economics is nothing more than accounting, and while accounts must be kept in medical practice as in other pro- fessions, the logic of the accounting is no different and the accountant has no special insights to offer. Much of economics does in fact depend on proper accounting: the creation of national accounts of income and product, starting more than a half-century ago, is the precursor of today's effort to create national health accounts 3 to show where the funds spent on health come from and where they go. But the interpretation of those flows does not follow only from their magnitude, but from economic theory about how doctors, patients, and financing agencies behave.

A third, even more mistaken reason, is summarized in the attitude that "health is not a business", or should not be one. Some doctors, and public health professionals in particular, often find it hard to accept that health care is financed, produced and delivered in a constellation of markets - as though markets or "business" were intrinsically inimical to human health. This argument usually rests on the claim that health care is a basic right or a basic need, and therefore too important to be left to markets. But food, which is a much more basic necessity than health care, is produced and delivered in markets, and there is nothing wrong with that. The question, in the case of health care, is whether those markets work in socially desirable ways, or whether they lead to situations in which some people cannot afford needed care, or the wrong kinds of care are produced, or at too high a cost, or something else goes wrong. Economics is, to a large extent, the science of how markets operate, so it is extremely relevant to markets in which failure may be a matter of life and death.

\section{What economics does a doctor not need to know?}

So it might be helpful for medical professionals to understand some economics, as it applies to medicine and health. Does that mean they need to comprehend all of economics, or would it be safe to ignore large areas of the subject? Fortunately, there is much that a doctor does not need to know, starting with the specific economic issues that arise in sectors very different from health. The frequent (and frequently loose) use of the adjective "social" to describe some sectors of the economy might suggest that medical professionals wanting to understand health economics need to know something about the economics of related sectors such as education. Fortunately, this is not the case: in economic terms these fields are much more different than they are alike, 4 
and although similar issues arise in both, 5 it is more confusing than helpful to think of a general economics of "the social sector". The peculiarities of health economics mean that a doctor wanting to learn something about it need not try to understand the economics of any other sector in detail.

Currently there is great interest in what might be called "the macroeconomics of health", and a Commission on Macroeconomics and Health 6 has been created to study particularly the question of whether better population health contributes to economic growth, making health even more of a paying investment than it has traditionally been considered from an individual's perspective. ${ }^{7}$ That is an interesting question, but health does not need to be subordinated to income or growth in order to be regarded as vitally important. (It is even dangerous to justify health investments by appealing to their effect on economic outcomes, since such investments may pay off best for young adults and thereby lead to discrimination against the very young and the very old). And even if there is a strong connection, it does not mean that medical professionals need to know anything about macroeconomic theory in order to learn something useful for their own field. All that a doctor should know is that there are good macroeconomic policies and bad ones, that inflationary populism is an undoubtedly bad policy and that poor macroeconomic management is bad for a country's health, particularly the health of poor people. Much of the criticism directed at "structural adjustment" and its supposed damaging effects on health really should be directed at the economic irresponsibility that sometimes made such adjustment necessary in the first place. 8

Of course, what economists think they know is often a mixture of what they know and what they only think, including their more ideological positions and beliefs. (The same is true of public health specialists, to be sure). One reason that doctors are reluctant to learn more economics is that they reject some views as ideological - sometimes with good reason, sometimes mistakenly. For example, the claim by economists that most of the time, markets are an efficient mechanism for allocating resources to production and consumption may sound like ideology, but it is actually a strong empirical proposition. The history of efforts to control prices, dictate production or otherwise interfere with the normal working of markets, including particularly the sad history of Soviet-style economic management, offers abundant evidence. However, the claim by some economists that all markets are basically alike, and that in particular markets work just as well in health care as anywhere else, is not well supported either theoretically or empirically but includes a large dose of ideology . One needs to understand how markets work, without being taken in by "the mystique of markets". 9

Doctors who have never talked much with economists - or who have had the misfortune to talk only to mediocre economists - often think that economists care only about efficiency and not at all about equity, equality, rights, or the suffering of the sick and the dispossessed. It is certainly true that in economic theory, it is easier to agree on what constitutes or leads to efficiency than to agree about equity; and it is also true that inefficiency means waste, which means less of something desirable for someone. But economic thought also includes a long and deep tradition of thinking about ethical issues, about what constitutes a just society, about rights and entitlements 10 and about the possible conflicts between equity and efficiency and the frequent necessity for choices among societal objectives. ${ }^{11}$ Even for such a relatively narrow question as what health interventions to purchase with public money, there are no fewer than nine relevant criteria, of which at least three concern equity rather than efficiency. 12 The conclusion to draw from all this is that a doctor wanting or needing to learn some economics does not have to abandon his or her ethical principles or political views. What he or she should be prepared to do is to question those principles and views in the light of economics and see how well they hold up. Economic thinking can help to identify contradictions or poorly formulated opinions. It does not impose a set of ethical or political suppositions or preferences (in fact, the economics of consumer behavior starts with an unquestioned respect for preferences).

\section{Understanding how economists think}

More than knowing any particular conclusion of economics, a doctor needs to understand the way that economists think: incomprehension and conflict arise more from differences in the way the two professions approach questions, than from the specific answers to those questions. An economist does not, contrary to popular superstition, think only or primarily about money, even if he or she often tries to find monetary equivalents of other measures. Economists think about resources, and particularly about whether those resources have prices and if so, whether they are the right prices to assure efficiency or equity. Since resources have costs, whether those 
are recognized or not, economists want to know if the use of those resources produces effects (non-monetary) or benefits (usually monetized) sufficient to justify how they are used. Much work in economics is devoted to comparisons among these concepts, under the names of cost-effectiveness analysis, cost-utility analysis or costbenefit analysis. ${ }^{13}$ It is important for doctors to understand that while costs are the specialty of economists, the definition and estimation of effects or outcomes is the province of medical professionals: these analyses have to be joint efforts. Given an estimate of an effect (deaths averted, for example), economists often then go on to try to put a monetary value on the result, and such efforts can be questioned and rejected. What a doctor needs to understand is that while any particular kind of effect can be related to costs without monetizing the effect, there is no common currency besides money in which to compare different kinds of effects (health outcomes versus education, say), and that to avoid monetary valuations is to abstain from all such cross-sectorial comparisons.

As mentioned earlier, economists naturally think about markets, ideally without any prior assumptions about how well they work. To reject the idea of markets because some market outcomes are inefficient or inequitable or both, is to miss one of the main ideas that economists always carry with them. But markets are not simply theaters in which two characters called "supply" and "demand" interact, important as those two concepts are. Markets are places where people interact, in many different roles, as payers, investors, providers, patients, consumers and citizens; so economists concentrate on the behavior that occurs in markets, and in particular on the incentives that people face to behave one way or another. It is true that economists tend to talk mostly about financial or economic incentives, because they understand those best. That does not mean that other incentives - the desire to help others, professional pride, and so on - do not matter, only that economic analysis starts by taking those for granted, and then asks what happens to behavior when prices, means of payment, regulations or other incentives are modified. Particularly in the health sector, the economic incentives are often perverse, acting contrary to the desired outcomes, so it is crucial to analyze them and correct them if possible.

In considering the incentives and regulations to behave one way or another, economists have to assume that behavior is not simply a collection of responses to random impulses, but that people have some set of goals or objective function, that they are trying to get the most (or the least) of something out of their actions. It makes a difference, sometimes a great difference, what those objectives are. For example, a producer of a good or service will behave differently, depending on whether he or she aims to maximize profits, to maximize revenue, to assure a particular level of income, to capture a particular share of a market, to minimize risk, or to produce the highest possible quality of output. Since objectives are not always stated, and may not even be clearly known to the agent whose behavior is of interest, there is necessarily some speculation involved, and the confrontation of different assumptions with observed behavior. In this respect, economics has much more in common with psychology than with accounting or engineering. Incentives, to be effective, have to work on people's objectives; misunderstanding what they want or are trying to do can lead to perverse incentives and unwanted outcomes.

Finally, economists pay much attention to who has, and who needs, how much and what kind of information. People make all kinds of decisions based on the information they have (or think they have), and entire markets can work badly when information is incomplete (no one knows) or asymmetric (buyers know more than sellers, or vice versa), particularly if revealing information would damage the interests of the person who has it. Ignorance is obviously dangerous in the face of an epidemic, or for a person who faces a risk but is unaware of it or does not respond to information about it. Smoking is a marked example of this danger. 14-16 Some kinds of information lend themselves to accounting and standardized reporting (the basis of national health accounts and of much of epidemiology), but others do not, because they concern only individual actors or are costly to collect or interpret. Medical professionals also recognize the importance of information for detection, diagnosis, treatment and evaluation. What economic thinking adds is the emphasis on how information or the lack of it influences behavior, with economically important consequences.

\section{Important specifics of health economics}

With some general understanding of how economists think and what they think about, a medical profissional can begin to learn something more specific from the application of economics to health and health care. One way to preceed is to study how a particular eminent health economist 17 approaches a series of interesting issue in "the health economy" of one country. Another approach is to pick out some general issues to define a minimum set of economic knowledge for a medical professional. There is no agreed-upon short list of the ten most important things to know: what follows is a suggestion as to several simple ideas that matter because they have medically and financially significant consequences. 
First, health is a very peculiar asset because unlike almost anything else, including even some other forms of human capital, it is almost entirely inalienable. One can donate blood or even a kidney to improve someone else's health, but "health" itself cannot be transferred, and one must have some state of health, however poor. Since health is subject to many random shocks of illness or accident, and since health care can be catastrophically costly, one needs insurance against financial risk as well as the protection against physical risks provided by good nutrition, exercise and a range of public health measures such as sanitation and immunization. But the character of health makes it harder to insure than other assets, especially since the value of one's health and the financial risk are not correlated with one's capacity to pay. Thus one of the principal obstacles to making a health system work properly, is the difficulty of financing it so as to provide a reasonable and affordable degree of protection to everyone, without creating incentives either to do without such protection or to over-use medical care because the cost is borne by others-and while assuring that subsidies flow in the desirable directions. This difficulty is independent of the amount spent on health.

The emphasis on financing in discussions of health economics is entirely justified, then; but a doctor also needs to understand that there are three parts to it. It matters not only how health is funded, that is, who pays for it and through what mechanisms (taxes, social security, voluntary insurance, charity, out of pocket payments) but also whether and how those funds are pooled to share risks among population groups, and how they are then used to purchase goods and services.18 Each of these stages presents its own set of questions and difficulties, often with conflicts between economic efficiency and equity or fairness.

One important source of conflict is that what people want in the way of health care does not necessarily match what doctors think people need; and when needs and demands do not coincide, it is impossible for the supply of services simultaneously to satisfy both of them. ${ }^{19}$ Several of the reasons why need, demand and supply do not automatically match up, go by the name of "market failure", meaning that while there is a working market for health care, it does not reach the kind of efficient equilibrium that a so-called perfect market would achieve. Doctors need to understand these reasons, which include standard economic concepts such as public goods, externalities, information failures, and non-competitive behavior. They also need to distinguish these problems from other reasons for unsatisfactory health outcomes which are just as important but which are not "failures" in the economist's sensesuch as poverty, and inequality of risks or of income.

"Failure" is one word to which economists give a fairly exact meaning that may not match the commonsense notion doctors are likely to have, and it is important, as in any dialog, to develop a clear, shared vocabulary. Arguing over whose definition to use, or not recognizing that the same word may be used in two meanings, is wasteful: the best example of this is the difference between the economist's term "public good" and the medical sense of "public health". All public goods in health are part of public health, but the converse is not true, and the difference matters for public policy.

Purchasing, the last stage of financing health, involves two complex questions: what to buy, and how to pay the providers - doctors, hospitals, vendors of goods and services. The difference between need and want, and the enormous variation in costs of medical procedures, are crucial for the first choice, as is the definition of what one is trying to achieve. Maximal overall population health as an objective will lead to different choices than improving the health of the worst-off, or giving everyone something like the same chance to have his or her health problems resolved. And doctors need to understand that while the size of a health problem - for example, the burden of disease attributed to a particular disease or condition - is highly relevant to how much it might cost to deal with the problem, decisions about what interventions should have priority do not depend simply on the magnitude of the problem.20,21 A full evaluation of a health system draws on many different kinds of information; 22 some ways of using or combining different kinds of data are useful or legitimate, and some are not.

Incentives are crucially important to the second question, and deciding on the best way to pay providers is greatly complicated by a feature that is peculiar to health care - the practice of referral from one level or type of facility or professional to another. There does not seem to be one ideal way to pay all the different providers involved in a system, so a doctor needs to understand the virtues and deficiencies of different payment systems (fee-for-service, global budget, per bed-day, for diagnostic-related groups, and so on) and how they interact. Aligning incentives and creating a good institutional environment is most important for hospitals, the most complex organizations in health system. 18

How to pay, as opposed to how much to pay, is an example of the importance of institutions and regulations in health economics: it is not a matter of 
costs, in the first instance, but it may have a large impact on both costs and health outcomes. More generally, doctors need to know that much of health economics is concerned with the rules of the game and not simply with the flows of money, goods and services. One particular issue of this sort is that of the right degree of autonomy for individual doctors and for the organizations in which they work and the organizations which purchase their services-which are not the same, when there is a "purchaserprovider split" between funding and purchasing agencies, and the producers of medical services. Too little autonomy, too much dictation from above or outside, is practically a guarantee of waste; too much freedom may be an invitation to abuse, low quality or excessive costs. As with many other issues, economics does not provide final answers, but it does offer a way of thinking about them that can facilitate better decisions and ultimately better outcomes.

\section{Gains from better understanding}

Suppose a medical professional accepts the need to understand some health economics, perhaps including the specific ideas just discussed. What can he or she hope to gain thereby? What is the likely pay-off for the effort involved in learning some new vocabulary, accepting new and different viewpoints, and possibly having to give up or modify some cherished ideas? The most obvious benefit is that it becomes easier to talk with economists, when one cannot avoid doing so-and as decisions about health care come to depend more and more on economic considerations, it becomes harder to keep economists out of the discussion. Doctors sometimes fear being crowded out of decisions over which historically they had full control. Perhaps the best way to assure that their knowledge and views continue to be respected is to learn something about the knowledge and views of the newcomers to the other side of the table. Reducing the level of incomprehension and antagonism that often characterizes such encounters at first, is worth some trouble.
Ideally, better mutual understanding between medical professionals and economists will actually improve the efficiency of health care, and maybe even its equity. By examining their own behavior and responses to incentives in the light of economics, doctors may see ways to be more effective or less wasteful of resources; and they should be better prepared to accept, and influence, reforms to how they work and how they are paid. There is nothing guaranteed, or easy, about reform processes in health, but they seem sure to work better when all involved have at least some knowledge of all the relevant factors. For society as a whole, a better working health system is clearly the greatest potential gain from a fuller understanding between the two professions.

Finally, at least for some medical professionals there can be a purely scientific or intellectual pleasure in exploring the thinking of another profession and thereby seeing one's own profession differently. Of course, this can lead to frustration, because the new ideas may be hard to put into practice and can lead to friction with one's own colleagues. This is especially likely when techniques of economic evalaution are stretched too far or their results conflict too strongly with perceived political imperatives. 22 But such stretching and conflict are often a necessary part of learning, and may ultimately be the basis for different political imperatives and reform opportunities.

\section{Acknowledgement}

I must thank Bertoldo Kruse Grande Arruda for inviting these reflections. Many colleagues and friends have contributed to these ideas, particularly those associated with the World Bank's Flagship Course in Health Reform. None of them bears any responsibility for what is said here. 


\section{References}

1. Kenneth A. Uncertainty and the welfare economics of medical care. Am Econ Rev 1963; 53: 941-73.

2. Anthony JC, Newhouse JP, editors. Handbook of health economics. Amsterdam: Elsevier; 2000. v. 17.

3. Poullier JP, Hernández P. Estimates of National Health Accounts (NHA) for 1997. Geneva: World Health Organization (WHO); 2000. (WHO/EIP Discussion paper, 27)

4. Castro CM, Musgrove P. On the nonexistence of 'the social sector', or why education and health are more different than alike". Washington, DC: Interamerican Development Bank; 2000. (Discussion paper).

5. Jiménez E. Pricing policy in the social sectors: cost recvery for education and health in developing dountries. Baltimore: Johns Hopkins University; 1987.

6. WHO. World Health Organization, CMH. Commission on Macroeconomics and Health. Evidence and information for policy: overview. Geneva: WHO; 2000.

7. Savedoff WD, Schultz TP, editors. Wealth from health: linking social investments to earnings in Latin America. Washington, DC: Interamerican Development Bank; 2000.

8. Garenne M, Gakusi E. Health effects of structural adjustment programs in sub-Saharan Africa. Paris: French Center for Population and Development Studies (CEPED); 2000. (Working paper).

9. Bennett S. The mystique of markets: public and private health care in devloping countries. London: London School of Hygiene and Tropical Medicine, Public Health and Policy Department; 1991. (Publication, 4).

10. Sem A. Poverty and famines: an essay on entitlement and deprivation. Oxford: Oxford University; 1982.

11. Okun AM. Equity and efficiency: the big trade-off. Washington, DC: Brookings Institution; 1975.
12. Musgrove P. Public spending on health care: how are different criteria related? Health Pol 1999;47: 207-22.

13. Drummond M, O'Brien B, Stoddart GL, Torrance GW. Methods for the economic evaluation of health care programmes. 2. ed. Oxford: Oxford University; 1997.

14. Jha P, Chaloupka FJ, editors. Tobacco control in developing countries. Oxford: Oxford University; 2000.

15. Jha $P$, Musgrove $P$, Chaloupka FJ, Yurekli A. The economic reationale for intervention in the tobacco market. In: Jha P, Chaloupka FJ, editors. Tobacco control in developing countries. Oxford: Oxford University; 2000. p. 153-74

16. Kenke D, Chen L. Consumer information and tobacco use. In: Jha P, Chaloupka FJ, editors. Tobacco control in developing countries. Oxford: Oxford University; 2000. p. 177-214.

17. Fuchs VR. The health economy. Cambridge, MA: Harvard University; 1986.

18. WHO. World Health Organization. World health report 2000. Health systems: improving performance. Geneva: WHO; 2000.

19. Musgrove P. Public and private roles in health: theory and financing patterns. Washington, DC: The World Bank; 1996. p. 23-4 (Discussion paper, 339).

20. Jamison DT, Mosley WH, Measham AR, Bobadilla JL. Disease control priorities in developing countries. Oxford: Oxford University; 1993.

21. The World Bank. World development report 1993: investing in health. Washington, DC: The World Bank; 1993.

22. Cumper GE. The evaluation of national health systems. Oxford: Oxford University; 1991. p. 12-17. (Oxford medical publications) 